RESEARCH ARTICLE

\title{
Effect of Graded Levels of Magnesium on Dry Matter Production and Yield of Maize Cultivated in Soils of Maize Growing Tracts in Pudukkottai District of Tamil Nadu
}

\author{
Sankaralingam P* and Malarvizhi $\mathbf{P}$ \\ Department of Soil Science and Agricultural Chemistry, \\ Tamil Nadu Agricultural University, Coimbatore-641 003
}

\begin{abstract}
In order to assess the effect of graded levels of applied magnesium (Mg) $\left(0,5,10,15,20\right.$ and $\left.25 \mathrm{~kg} \mathrm{ha}^{-1}\right)$ on the soil available major nutrients, field experiments were conducted in 14 farmer's holdings at Pudukkottai district with hybrid maize (NK 6240) as a test crop. Dry matter production (DMP) of the whole plant (above ground) at harvest stage of maize was significantly influenced by the application of $100 \%$ NPK $+10 \mathrm{~kg} \mathrm{Mg} \mathrm{ha}^{-1}$ and recorded the highest mean as $25620 \mathrm{~kg}^{-1}$ at harvest stage. A noticeable increase in grain and stover yield of maize crop was manifested by applying 100\% NPK $+10 \mathrm{~kg} \mathrm{Mg} \mathrm{ha}^{-1}$ which recorded the highest mean yield as $11.6 \mathrm{t} \mathrm{ha}^{-1}$ and 14.0 t ha $^{-1}$, respectively. It reported a 14.31 and 22.25 per cent increase in grain and stover yields, respectively, over control.
\end{abstract}

Keywords: Available magnesium; Graded levels;Critical limit;Maize; Pudukottai

\section{INTRODUCTION}

Maize is a versatile crop having higher yield potential among cereals and it is cultivated over a wide range of agro climatic zones, hence popularly called as "Queen of Cereals". India is the fifth-largest producer of maize in the world, contributing 3\% of global production and cultivated in 9.20 million ha with the production of 23.67 million tonnes and an average yield of $5564 \mathrm{Kg} \mathrm{ha}^{-1}$. In Tamil Nadu, it is cultivated in 3.42 lakh ha area with a production of 18.33 lakh tonnes with an average yield of $5359 \mathrm{~kg} \mathrm{ha}^{-1}$ (Anon, 2019). By 2022, the requirement of maize for various sectors is around 100 million tonnes, of which nearly $28 \%$ of maize to be produced is needed for food purpose, $11 \%$, as livestock feed, $48 \%$ as poultry feed, $12 \%$ for starch in wet milling industry and oil production and one per cent as seed. Maize is the important food grain crop in India and one of the most important cereal crops in the world's agricultural economy, which is gaining popularity among Indian farmers due to its high yielding potential. Magnesium is a component of the chlorophyll molecule and is essential for photosynthesis. It is also a phosphorus carrier in plants. Plants without magnesium would not be able to take up phosphorus. It is essential for phosphate metabolism, plant respiration, and the activation of enzyme systems in plants (Beegle, 2013). The plant, as the $\mathrm{Mg}^{2+}$ divalent cation takes up magnesium. As magnesium-containing minerals in the soil slowly weather, some magnesium is made available to plants. The supply of available magnesium can be lost or deleted through leaching, plant uptake, and removal processes. The availability of magnesium to plants is often related to soil $\mathrm{pH}$, with supply decreasing in low and high $\mathrm{pH}$ soil.

Magnesium plays an important role in chlorophyll molecules, which is the key plant component responsible for carbon dioxide fixation (Grzebisz et al., 2010). Magnesium is the central core of the chlorophyll molecule in plant tissue. Thus, if magnesium is deficient, the shortage of chlorophyll results in poor and stunted plant growth. Magnesium is also an integral component of large number of enzymes in plants viz., alcohol dehydrogenase, carbonic anhydrase, Cu- magnesium superoxide dismutase, alkaline phosphatase, phospholipases, carboxy peptidases and RNA polymerases. Magnesium serves as a co-factor in most enzymes that activate phosphorylation processes by acting as a bridge between pyrophosphate structures of ATP or ADP, DNA, RNA and the enzyme molecules, essential for amino acid and fat synthesis (Mengel and Kirkby, 2001). Magnesium is absorbed as $\mathrm{Mg}^{2+}$ and is mobile in plants, moving from the older to the younger leaves. Low cation exchangeable capacity, cation competition and particularly long-term imbalanced fertilization of nitrogen, phosphorus and potassium (NPK) are possible reasons for $\mathrm{Mg}$ deficiency in highly weathered, sandy and acidic soils (Gransee and Fuhrs, 2013). Among the cereal 
crops, maize and wheat are highly susceptible to magnesium deficiency. The most distinct magnesium deficiency symptoms are stunted growth and little leaf, which are presumably related to disturbance in the metabolism of auxin and indole acetic acid in particular. The study revealed that the early application of fertilizer could enhance the yield of maize at two weeks after planting. These results are discussed in the light of time of fertilizer application on growth and yield attributes of maize.

Magnesium sulphate fertilizer is designed to easily correct or even,magnesium deficiencies for all types of crops and soil conditions. It leaches calcium and potassium from the soil. Magnesium is the central atom amid four nitrogen atoms in the chlorophyll molecule,and hence involved in photosynthesis and also as an activator for many enzymes required in plant growth processes and stabilizes the nucleic acids. Plants use magnesium ions to make chlorophyll in their leaves. Like in nitrate deficiency, the plant is limited in terms of its photosynthetic ability and the plant growth is compromised. Magnesium is a limiting factor in healthy plant growth.

Research studies regarding magnesium application has insisted that magnesium supplementation increases magnesium accumulation in the leaf tissue by $34.3 \%$ and concentration of sugar in edible organs by $5.5 \%$ higher as compared to non- magnesium supplemented treatments (Zhengwang et al., 2020). Magnesium deficiency can be overcome with dolomite (a mixed magnesium-calcium carbonate), magnesite (magnesium oxide) or epsom salts (magnesium sulphate).

To know the current status of available magnesium in soil and the impact of graded levels of magnesium fertilizer application on the biomass and yield of grains and stover this study was undertaken Materials and Methods.

The basic survey was undertaken to collect soil samples from major maize growing tracts in Pudukkottai district of TamilNadu. Gandarvakotttai, Karambakudi, Pudukkottai, Aranthangi, Kunnandarkoil, Arimalam, Tiruvarankulam and Annavasal blocks were identified as major maize growing block and 256 soil samples were collected randomly. The collected soil were processed and analysed for various parameters such as $\mathrm{pH}, \mathrm{EC}$, $\mathrm{Mg}$ and $\mathrm{Ca}$ The soil were grouped based on $\mathrm{Mg}$ status as seven different categories such as ., $<25$ $\mathrm{mg} \mathrm{kg}^{-1}, 25-50 \mathrm{mg} \mathrm{kg-}^{-1}, 50-75$ mg kg-1, 75-100 mg $\mathrm{kg}^{-1}, 100-150 \mathrm{mg} \mathrm{kg}^{-1}, 150-300 \mathrm{mg} \mathrm{kg}^{-1}$ and $>300$ $\mathrm{mg} \mathrm{kg-1}$ to conduct the pot and field experiments.

\section{Pot experiment}

Five kilograms of processed soil were weighed and added in the pots which were imitated thrice in a Completely Randomized Design. Few maize seeds (Hybrid Maize NK 6240 were planted per pot and 10 days after germination, one seedling was kept up in the pot. Suggested levels of NPK (250:75:75 kg ha$\left.{ }^{1}\right)$ were given consistently in arrangement structure to every one of the pots. Nitrogen was applied in three parts such as., $25 \%$ as basal, $50 \%$ on 25 days after sowing and $25 \%$ at 45 days after sowing, full dose of phosphorus and potassium were applied as basal. Graded levels of Mg such as., 0,5, 10, 15, 20 and $25 \mathrm{~kg} \mathrm{ha}^{-1}$ were applied as $\mathrm{Mg} \mathrm{SO}_{4}$. The crop was raised up to the tasselling stage and the plant tests (over the ground biomass) were drawn and $\mathrm{Mg}$ concentration was analysed. The soil samples were also collected at the tasselling stage and analyzed for different parameters.

\section{Soil characteristics}

Representative soil samples collected from the experimental fields were processed and analyzed for various physico-chemical properties. The $\mathrm{pH}$ of the initial soil ranged from 6.4 to 8.1 which was acidic to marginally basic. The EC of the soil indicated that they were liberated from saltiness. The soil from various locations showed different textural classes' such as., sandy loam to sandy clay loam. The bulk density and the particle density of the soil ranged from 1.41 to $1.76 \mathrm{Mg} \mathrm{m}^{-3}$ and 2.40 to $2.66 \mathrm{Mg} \mathrm{m}^{-3}$, respectively. The organic carbon content ranged between 0.45 to 0.86 per cent, which is of low to medium status. The soil available $\mathrm{Mg}$ status fell under low, medium and high categories respectively.

\section{RESULTS AND DISCUSSION}

Application of $100 \% \mathrm{NPK}+10 \mathrm{~kg} \mathrm{Mg} \mathrm{ha}{ }^{-1}$ recorded the highest mean grain yield of $9075 \mathrm{~kg}$ ha ${ }^{-1}$, which was on par with $100 \% \mathrm{NPK}+15 \mathrm{~kg} \mathrm{Mg}$ $\mathrm{ha}^{-1}$ with $9000 \mathrm{~kg} \mathrm{ha}^{-1}$. The lowest mean grain yield of $8002 \mathrm{~kg} \mathrm{ha}^{-1}$ in all the locations was recorded in control. Among all the locations, $L_{7}$ ( 75 to $100 \mathrm{mg} \mathrm{kg}$ $\left.{ }^{1}\right)$ recorded the highest mean grain yield of $10897 \mathrm{~kg}$ ha-1, followed by $\mathrm{L}_{6}$ (50 to $\left.75 \mathrm{mg} \mathrm{kg}^{-1}\right)\left(10587 \mathrm{~kg} \mathrm{ha}^{-1}\right)$. The locations $L_{7}$ (75 to $100 \mathrm{mg} \mathrm{kg}^{-1}$ ) (11604 kg ha-1) and $L_{6}\left(50\right.$ to $75 \mathrm{mg} \mathrm{kg}^{-1}$ ) (11556 $\mathrm{kg} \mathrm{ha}^{-1}$ ) recorded the highest grain yield with the application of $100 \%$ NPK $+10.0 \mathrm{~kg} \mathrm{Mg} \mathrm{ha}^{-1}$. Application of $100 \% \mathrm{NPK}+15$ $\mathrm{kg} \mathrm{Mg} \mathrm{ha}^{-1}$, recorded the highest grain yield of 11427 $\mathrm{kg} \mathrm{ha}^{-1}$ and $10999 \mathrm{~kg} \mathrm{ha}^{-1}$ were observed in locations $\mathrm{L}_{7}$ and $\mathrm{L}_{6}$. The soil with low to medium levels of initial soil Mg content responded positively to the the $\mathrm{Mg}$ application and the highest mean grain yield of 10897 $\mathrm{kg} \mathrm{ha}^{-1}$ and $10587 \mathrm{~kg} \mathrm{ha}^{-1}$ was observed in the location $L_{7}$ and $L_{6}$ respectively, whereas in the locations $L_{9}$ to $\mathrm{L}_{14}$, where the initial soil Mg content was high level registered a declining trend of grain yield to the application of $\mathrm{Mg}$ was registered the lowest mean grain yield of $7204 \mathrm{~kg} \mathrm{ha}^{-1}$ was recorded in location 
$\mathrm{L}_{11}$. In the control plot, the overall values ranged from 6311 to $9750 \mathrm{~kg} \mathrm{ha}^{-1}$ across the locations. Crop growth and grain yield were positively correlated with intending at nutrients to the soil. The grain and straw yield of maize crops were significantly increased by the application of Mg fertilizer. The increased yield registered in this field study could be attributed to the effect of Mg on plant growth especially enhanced enzymatic activity. The Mg fertilization improved the synthesis and transport of carbohydrate to grains. The application of Mg established better source link relationship, thus influenced the grain yield. Similar findings were also found in the experiments conducted by Ramanjineyulu et al., 2018, El-Dissoky et al. (2017) and Jan Bocianowski et al.(2015).

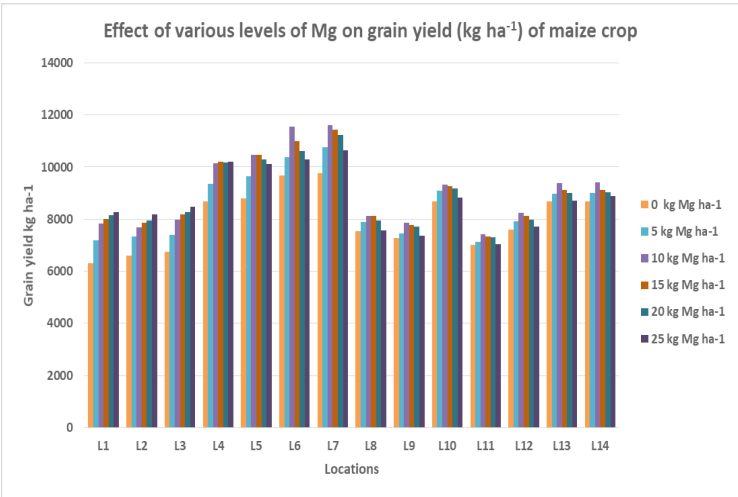

Figure 1. Effect of various levels of $\mathrm{Mg}$ on grain yield ( $\left.\mathrm{kg} \mathrm{ha}^{-1}\right)$ of maize crop.

The stover yield recorded a positive response with the supplementation of $\mathrm{Mg}$ at different levels. The stover yield obtained in various locations showed a positive response to the application of different levels of Mg. Among the different levels of $\mathrm{Mg}$ application, application of $100 \% \mathrm{NPK}+10.0 \mathrm{~kg} \mathrm{Mg} \mathrm{ha}^{-1}$ recorded the highest mean stover yield of $10855 \mathrm{~kg} \mathrm{ha}^{-1}$, which was on par with $100 \% \mathrm{NPK}+15.0 \mathrm{~kg} \mathrm{Mg} \mathrm{ha}^{-1}$ (10769 $\mathrm{kg} \mathrm{ha}^{-1}$ ) and $100 \% \mathrm{NPK}+20.0 \mathrm{~kg} \mathrm{Mg} \mathrm{ha}^{-1}(10652 \mathrm{~kg}$ $\mathrm{ha}^{-1}$ ) with the highest per cent stover yield of 13.47 and 12.56 per cent over control. The locations $L_{1}$ to $L_{7}$ with initial soil Mg content was low to medium status showed a positive response to the application of $\mathrm{Mg}$, whereas the locations $\mathrm{L}_{8}$ to $\mathrm{L}_{14}$ (having high soil $\mathrm{Mg}$ content was high) showed a decreasing trend in stover yield. Among the different locations, highest mean stover yield of $13090 \mathrm{~kg} \mathrm{ha}^{-1}$ was noted at $\mathrm{L}_{7}$ (75 to $100 \mathrm{mg} \mathrm{kg}^{-1}$ ) and in location $\mathrm{L}_{11}$ (150 to 300 $\mathrm{mg} \mathrm{kg}^{-1}$ ) the lowest mean stover yield of $8599 \mathrm{~kg} \mathrm{ha}^{-1}$ was recorded. In all the locations, the control plot registered the lowest stover yield, which varied from 7482 to $11705 \mathrm{~kg} \mathrm{ha}^{-1}$. The stover yield of all the field trials in this study generated positive response with the supplementation of Mg at different levels. The highest mean stover yield of maize crop was recorded in $100 \% \mathrm{NPK}+10 \mathrm{~kg} \mathrm{Mg} \mathrm{ha}^{-1}$. Among the locations, $L_{1}$ to $L_{7}$ (where the initial soil available Mg content was low to medium) showed positive response where as the locations $L_{8}$ to $L_{14}$ (where the soil available $\mathrm{Mg}$ content was high) showed declining trend in stover yield.

It is noticed that the soil with medium levels of initial soil available $\mathrm{Mg}$ content in $\mathrm{L}_{7}$ recorded the highest mean stover yield among the 14 locations and the lowest was observed in the field location $\mathrm{L}_{11}$ with high levels of initial soil available Mg. The similar finding was recorded by Ei Dissoky et al. (2017), Asangi et al. (2018), Ramanjineyulu et al. (2018) reported that the addition of $\mathrm{Mg}$ up to 20 $\mathrm{kg} \mathrm{ha}^{-1}$ enhanced the mean grain and straw yield.

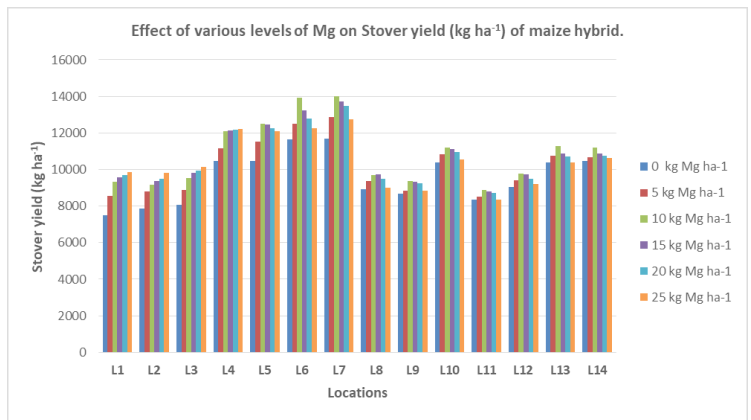

Figure 2. Effect of various levels of $\mathrm{Mg}$ on stover yield ( $\left.\mathrm{kg} \mathrm{ha}^{-1}\right)$ of maize hybrid.

Application of Mg recorded a significant impact on dry matter production (DMP) of maize crop in a positive way. In locations $L_{1}$ to $L_{4}$ (soil with low degree of initial soil Mg status), the mean DMP was increasing with the application of Mg fertilizers (the soil with medium to high levels of initial soil Mg content), the mean DMP was inconsistent. The mean biomass yield increased from $17567 \mathrm{~kg} \mathrm{ha}^{-1}$ to $19930 \mathrm{~kg} \mathrm{ha}^{-1}$ and the maximum biomass yield of $19930 \mathrm{~kg} \mathrm{ha}^{-1}$ was noticed with the application of 100 per cent NPK+ $10 \mathrm{~kg} \mathrm{Mg} \mathrm{ha}^{-1}$ followed by Mg @ $15 \mathrm{~kg} \mathrm{ha}^{-1}$ with a yield of $19769 \mathrm{~kg} \mathrm{ha}^{-1}$. Minimum biomass yield of $17567 \mathrm{~kg} \mathrm{ha}^{-1}$ was recorded in the control treatment (100\% RDF).

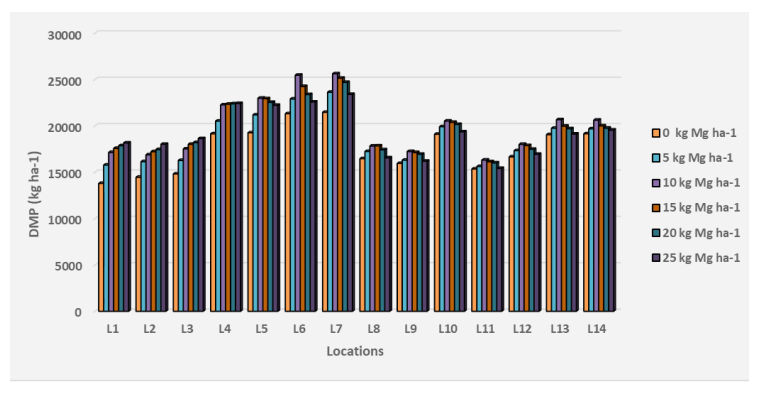

Figure 3. Effect of different levels of $\mathrm{Mg}$ on the DMP of maize at harvest

The mean biomass yield ranged from 15804 to $23987 \mathrm{~kg} \mathrm{ha}^{-1}$ in different locations. Application of Mg@ $10 \mathrm{~kg} \mathrm{ha}^{-1}$ significantly increased the biomass yield $\left(25620 \mathrm{~kg} \mathrm{ha}^{-1}\right.$ ) in $\mathrm{L}_{7}$ (75 to $100 \mathrm{mg} \mathrm{kg}^{-1}$ ) followed by $\mathrm{L}_{6}$ ( 50 to $75 \mathrm{mg} \mathrm{kg}^{-1}$ ) (25463 kg ha-1) and 
the least DMP was recorded in $\mathrm{L}_{1}\left(<25 \mathrm{mg} \mathrm{kg}^{-1}\right)$ with $17136 \mathrm{~kg} \mathrm{ha}^{-1}$. The data on dry matter production of the whole plant at harvest was positively correlated with the application of Mg. This might be due to the significant increase in the accumulation of photosynthetic pigments and the total chlorophyll contents increasing the photosynthetic efficiency of maize plants. Chen et al.(2017), reported similar findings earlier. Significant difference in biomass yield was recorded over control by the application at different levels of Mg. The minimum biomass yield was recorded in the control. The variation in DMP in different field locations may be due to the availability and application of $\mathrm{Mg}$. The significant increase in DMP in this study might be due to the stimulation and improvement of catalytic, co-catalytic and structural functions of Mg-containing enzymes and also the nutrient uptake. Asangi et al. (2018) reported that a similar result in maize was observed due to the application of the distillery spent wash $\mathrm{RO}$ reject to soil. The result of this study regarding DMP is in consonance with the findings of Canizella et al. (2017).

\section{CONCLUSION}

Dry matter production (DMP) of the whole plant (above ground) at the harvest stage of maize was significantly influenced by the application of $100 \%$ $\mathrm{NPK}+10 \mathrm{~kg} \mathrm{Mg} \mathrm{ha}^{-1}$ and recorded the highest mean as $25620 \mathrm{~kg} \mathrm{ha}^{-1}$ at the harvest stage. A noticeable increase in grain and stover yield of the maize crop was manifested by the application of $100 \%$ NPK + $10 \mathrm{~kg} \mathrm{Mg} \mathrm{ha}^{-1}$ which recorded the highest mean yield as 11.6 t ha $^{-1}$ and 14.0 t ha $^{-1}$, respectively. Therefore, it is concluded that the addition of magnesium fertilizers at the optimal level of $10 \mathrm{~kg} \mathrm{Mg}$ ha-1 and the recommended levels of NPK fertilization (100 percent) recorded higher grain yield and enhanced biomass.

\section{COMPETING INTERESTS}

There were no conflict of interest in the publication of this content

\section{REFERENCES}

Asangi, A. M., Srinivasamurthy, C. A. and S. Bhaskar. 2018. Variation in growth parameters of maize (Zea mays L.) at different growth stages due to onetime application of distillery spent wash $\mathrm{r}$ o reject. Int. J. of Chemical Studies., 6(3): 520-523.

Canizella, B. T., Souza, J. A., Moreira, A. and L. A. C. Moraes. 2017. Magnesium and zinc interaction in four soybean cultivars with different nutritional requirements. J. of Plant Nutrition., 41: 21892199.
Chen, P., Du, Q., Liu, X., Zhou, L., Hussain, S., Lei, L. and F. Yang. 2017. Effects of reduced nitrogen inputs on crop yield and nitrogen use efficiency in a long-term maize-soybean relay strip intercropping system. PloS one.,12: 1123-1129

Grzebisz Witold. 2013. Crop response to magnesium fertilization as affected by nitrogen supply. Plant and Soil., 368: 23-39.

Mengel, K. and E.A. Kirkby. 2001. Principles of Plant Nutrition. Kluwer Academic Publishers, Dordrecht, 849. http://dx.doi.org/10.1007/978-94-0101009-2.

Ramanjineyulu, M., Srinivasa Reddy, M., Ramesh Babu P. V. and P. Kavitha. 2018. Response of Maize (Zea mays L.) in Uptake of Micronutrients at Developmental Stages by Foliar Application of Secondary and Micronutrients. Int. J. Pure App. Biosci., 6(5): 297-303.

Zheng wang, Mahmood UI Hassan, Faisal Nadeem, Liangquan Wu, Fusuo Zhang, and Xuexian Li. 2020. Magnesium Fertilization Improves Crop Yield in Most Production Systems: A MetaAnalysis. Front Plant Sci., 10: 1727. DOI-10.3389/ fpls.2019.01727.

Zhang F. S., Wang J. Q., Zhang W. F., Cui Z. L., Ma and Q X. P. Chen. 2008. Nutrient use efficiencies of major cereal crops in China and measures for improvement. Acta Pedologica Scienca., 5(45): 915-924.DOI-10.1163/15693930878312278.

Siyal, A. A., Siyal, A. G. and Z. A. Abrol. 2002. Salt affected soils, their identification and reclamation. Pakistan J. of Appl. sci., 5: 537-540.

U. F. Chiezey .2014. Field Performance of Quatity Protein Maize With Zinc and Magnesium Fertilizers in the Sub-Humid Savanna of Nigeria. J of Agrl Sci ., 6(3): P 84-91

El-Dissoky R. A., Faten A. Al-Kamar and R. M. Derar.2017. Impact of Magnesium Fertilization on Yield and Nutrients Uptake by Maize Grown on two Different Soils. Egypt. J. Soil Sci.,57(4): 455 - 466

Altarugio L M., Marcos HL, Nirschl M G and Silvano R G,.2017. Yield performance of soybean and corn subjected to magnesium foliar spray. Pesq. agropec. bras Brasília., 52(12): 1185-1191.

Jan Bocianowski .,Piotr Szulc and Kamila Nowosad.2015. Parallel Coordinate Plots of Maize Traits Under Different Magnesium Application. Journal of Integrative Agriculture Advance., 14(2): 593-597

Shamsun Noor ,Md. Monirul Islam,Nirmal Chandra Shil and Md. Abu Kawochar. 2015. Effect of magnesium on crop yields within maize-green manure-T. aman rice cropping pattern on acid soil.Journal Arch.of Agron. and Soil Sci.,61(10): 1381-1392

Gransee, A., and Führs, H. 2013.Magnesium mobility in soils as a challenge for soil and plant analysis, magnesium fertilization and root uptake under adverse growth conditions. Plant Soil., 368: 5-21. 